\title{
PENGARUH SUPLEMENTASI MULTIVITAMIN MINERAL TERHADAP STATUS GIZI DAN KESEHATAN
}

\author{
Rimbawan'; Dadang Sukandar'; Febrina Sulistiawati' dan Fitrah Ernawati ${ }^{2}$ \\ ${ }^{1}$ Pengajar Departemen Gizi Masyarakat Institute Pertanian Bogor (IPB) \\ ${ }^{2}$ Mahasiswa S3 Program Studi IImu Gizi Masyarakat Institute Pertanian Bogor (IPB)
}

\section{ABSTRACT \\ THE EFFECT OF MULTIVITAMIN MINERAL SUPPLEMENTATION ON NUTRITIONAL STATUS AND HEALTH}

\begin{abstract}
Use of multivitamin mineral (MVM) supplement has grown rapidly over the past several decades. According to several studies, supplement users tend to have higher micronutrient intakes from their diet than nonusers. Consequently, they have an increased intake but are also more likely to exceed the upper level. The study was aimed to analyze the effect of MVM supplementation on renal function through the double blind randomized controlled trial. Subjects were 93 of the female workers in PT Ricky Putra Globalindo Tbk, Citeureup, Bogor who were randomly allocated to three treatments. The first received only placebo (without vitamin C and MVM); the second received $1000 \mathrm{mg}$ vitamin C; and the third received MVM supplement that contains $1000 \mathrm{mg}$ vitamin $\mathrm{C}, 45 \mathrm{mg}$ vitamin E, $700 \mu \mathrm{g}$ vitamin A, 6,5 mg vitamin $B_{6}, 400 \mu \mathrm{g}$ folic acid, 9,6 $\mu \mathrm{g}$ vitamin $\mathrm{B}_{12}, 10 \mu \mathrm{g}$ vitamin D, $10 \mathrm{mg} \mathrm{Zn,} 110 \mu \mathrm{g} \mathrm{Se}, 0,9$ $\mathrm{mg} \mathrm{Cu}$, and $5 \mathrm{mg} \mathrm{Fe}$. The supplements were distributed and consumed daily during 10 weeks. The mean change before and after study were tested with $t$ paired test. The results showed the BMI, systolic and diastolic blood pressure, urea and creatinine blood serum were not significantly different before and after study $(p>0,05)$. The distribution of female workers based on BMI showed that more than half of them have normal nutritional status $\left.(B M I) 18,5-24,9 \mathrm{~kg} / \mathrm{m}^{2}\right)$. The distribution based on systolic and diastolic blood pressure showed that most of them were not hypertension (systolic $<140$ $\mathrm{mmHg}$, diastolic $<90 \mathrm{mmHg}$ ); and the distribution based on urea and creatinine showed that most of them have normal status (urea 8,0-25,0 mg/dl; creatinine 0,6-1,5 mg/dl).
\end{abstract}

Keywords: food supplement, BMI, blood pressure, urea, creatinine.

\section{PENDAHULUAN}

$\mathrm{S}$ aat ini penggunaan suplemen semakin meningkat, dan sepertinya akan terus menerus bertambah'. ${ }^{1} \mathrm{Di}$ Inggris, tidak kurang dari 40 persen penduduk mengkonsumsi suplemen secara teratur ${ }^{2}$. Sementara itu, lebih dari setengah orang dewasa di Amerika dilaporkan menggunakan suplemen makanan. Pada umumnya, mereka mempercayai bahwa suplemen dapat membuat mereka berada dalam kondisi yang lebih baik, memberikan tambahan energi, meningkatkan kesehatan, serta mencegah dan mengobati penyakit ${ }^{3}$.

Menurut beberapa penelitian, masyarakat yang mengkonsumsi suplemen multivitamin mineral cenderung memiliki intik mikronutrien yang lebih tinggi dibandingkan masyarakat yang tidak mengkonsumsi suplemen. Intik tambahan yang diperoleh dari suplemen ini kemungkinan besar dapat melebihi batas maksimum yang diperbolehkan (tolerable upper intake leve//L) sehingga membahayakan kesehatan. Penelitian ini bertujuan untuk melihat pengaruh suplementasi multivitamin mineral terhadap status gizi dan kesehatan.

\section{BAHAN DAN CARA}

Analisis ini menggunakan data dari penelitian "Pengaruh Suplementasi Multivitamin Mineral terhadap Fungsi Imun dan Antioksidan" yang mempunyai data fungsi ginjal dan belum digunakan. Desain penelitian utama adalah RCT-double blind.

\section{Lokasi dan Sampel Penelitian \\ Penelitian dilakukan di Pabrik Garmen PT RPG., Citeureup, Bogor dimulai pada}


bulan Februari hingga Desember 2008. Sampel adalah karyawati PT RPG. yang sudah menikah berusia 20-45 tahun. Jumlah sampel dalam penelitian ini terdiri dari: 31 orang pada perlakuan plasebo, 31 orang pada perlakuan vitamin $\mathrm{C}$, dan 31 orang pada perlakuan multivitamin mineral, sehingga jumlah total sampel 91 orang.

\section{Data yang Dikumpulkan}

Usia sampel didapat dengan cara wawancara dan dikategorikan menjadi 3 kategori: 20-29 tahun, 30-39 tahun, dan $\geq 40$ tahun. Ukuran keluarga dikategorikan menurut BPS menjadi keluarga kecil $(\leq 4$ orang), sedang (5-7 orang), dan besar ( $>7$ orang). Tingkat konsumsi energi dan protein dikategorikan menjadi 4 kategori, yaitu defisit tingkat berat jika tingkat konsumsi $<70 \%$, defisit tingkat ringan jika tingkat konsumsi $70-80 \%$, cukup jika tingkat konsumsi 80 $90 \%$, dan normal jika tingkat konsumsi $>90 \%{ }^{4}$. IMT dikategorikan menjadi 5 kategori: gizi buruk bila IMT $<17,0 \mathrm{~kg} / \mathrm{m}^{2}$, gizi kurang : IMT $17,0-18,4 \mathrm{~kg} / \mathrm{m}^{2}$, gizi baik : IMT $18,5-24,9 \mathrm{~kg} / \mathrm{m}^{2}$, gizi lebih (overweight) : IMT 25,0 - 27,0 kg/m², obesitas (IMT >27,0 $\left.\mathrm{kg} / \mathrm{m}^{2}\right)^{5}$. Lama hari sakit adalah jumlah hari sakit yang diderita oleh sampel selama masa suplementasi (10 minggu). Tekanan darah adalah kondisi kesehatan wanita pekerja yang dinyatakan dalam tekanan darah sistolik dan diastolik, dikatakan hipertensi jika tekanan darah sistolik $\geq 140 \mathrm{mmHg}$ dan diastolik $\geq 90 \mathrm{mmHg}$, dan tidak hipertensi jika tekanan darah sistolik $<140 \mathrm{mmHg}$ dan diastolik $<90 \mathrm{mmHg}^{6}$. Urea dikatakan normal jika kadarnya dalam darah 8,0-25,0 mg/dl; sedangkan kreatinin dikatakan normal jika kadarnya dalam darah $0,6-1,5 \mathrm{mg} / \mathrm{dl}^{7}$.

\section{Pengolahan dan Analisis Data}

Data dianalisis secara deskriptif dan inferensia menggunakan program SPSS for Windows versi 12.0. Untuk mengetahui keragaman data awal akan dilakukan uji analisis ragam (analysis of variance/ANOVA). Untuk mengetahui perubahan variabel sebelum dan setelah perlakuan digunakan uji t-berpasangan ( $t$ paired test).

\section{HASIL}

\section{Karakteristik Sampel}

Pada Tabel 1menunjukan sebaran wanita pekerja berdasarkan kategori usia, dimana sebagian besar wanita pekerja berusia antara 30-39 tahun $(52,7 \%)$. Wanita pekerja yang berusia antara 20-29 tahun sebanyak 39,8 persen; sedangkan yang berusia $\geq 40$ tahun sebanyak 7,5 persen. Usia terendah wanita pekerja adalah 24 tahun, sedangkan usia tertinggi adalah 45 tahun.

Tabel 1

Sebaran Wanita Pekerja Menurut Kategori Usia

\begin{tabular}{lcc}
\hline Usia & $\mathrm{n}$ & Persentase $(\%)$ \\
\hline 20-29 tahun & 37 & 39,8 \\
30-39 tahun & 49 & 52,7 \\
$\geq 40$ tahun & 7 & 7,5 \\
\hline Total & 93 & 100,0 \\
\hline
\end{tabular}

Tabel 2 menunjukkan sebaran ukuran keluarga wanita pekerja. Sebagian besar keluarga wanita pekerja termasuk dalam kategori keluarga kecil $(93,5 \%)$; dan sisanya termasuk dalam keluarga sedang $(6,5 \%)$. 
Tabel 2

Sebaran Ukuran Keluarga Wanita Pekerja

\begin{tabular}{lcc}
\hline Ukuran keluarga & $\mathrm{n}$ & Persentase $(\%)$ \\
\hline Kecil ( $\leq 4$ orang) & 87 & 93,5 \\
Sedang (5-7 orang) & 6 & 6,5 \\
Besar (>7 orang) & 0 & 0,0 \\
\hline Total & 93 & 100,0 \\
\hline
\end{tabular}

Tabel 3

Rata-rata ( \pm SD) Konsumsi Energi dan Protein Sampel dari Makanan Sebelum Suplementasi

\begin{tabular}{lcccccc}
\hline \multirow{2}{*}{ Zat Gizi } & \multicolumn{6}{c}{ Perlakuan } \\
\cline { 2 - 7 } & $\begin{array}{c}\text { Rata-rata } \\
( \pm \text { SD })\end{array}$ & $\%$ AKG & $\begin{array}{c}\text { Rata-rata } \\
( \pm S D)\end{array}$ & $\%$ AKG & $\begin{array}{c}\text { Rata-rata } \\
( \pm S D)\end{array}$ & $\%$ AKG \\
\hline Energi (kkal) & $1253 \pm 402$ & 69,6 & $1199 \pm 388$ & 70,6 & $1019 \pm 311$ & 58,5 \\
Protein (g) & $42,8 \pm 12,6$ & 87,6 & $40,5 \pm 13,2$ & 87,0 & $36,5 \pm 12,7$ & 76,5 \\
\hline
\end{tabular}

Pada tabel di atas dapat dilihat bahwa pada konsumsi energi sebelum suplementasi, rata-rata sampel pada perlakuan plasebo dan multivitamin mineral mengalami defisit tingkat berat (tingkat konsumsi $<70 \%$ ), sedangkan rata-rata sampel pada perlakuan vitamin $\mathrm{C}$ mengalami defisit tingkat ringan (tingkat konsumsi 70 $80 \%$ ). Pada konsumsi protein, rata-rata sampel pada perlakuan multivitamin mineral mengalami defisit tingkat ringan (tingkat konsumsi $70-80 \%$ ), sedangkan pada plasebo dan vitamin $\mathrm{C}$ tingkat konsumsinya cukup (tingkat konsumsi 80-90\%).

\section{Pengaruh Pemberian Multivitamin Mineral}

Tabel 4 menunjukkan bahwa tingkat konsumsi energi pada perlakuan plasebo setelah intervensi tidak berubah, masih tetap dalam kategori defisit tingkat berat (tingkat konsumsi <70\%), sedangkan perlakuan vitamin C setelah suplementasi menurun menjadi dalam kategori defisit tingkat berat (tingkat konsumsi $<70 \%$ ), sementara itu sampel pada perlakuan multivitamin mineral sebelum intervensi termasuk dalam kategori defisit berat menjadi defisit tingkat ringan (tingkat konsumsi $70-80 \%$ ). Untuk tingkat konsumsi protein, sampel pada perlakuan plasebo dan vitamin $C$ setelah suplementasi termasuk dalam kategori cukup (tingkat konsumsi 80-90\%), sedangkan pada multivitamin mineral termasuk dalam kategori normal (tingkat konsumsi $>90 \%$ ). Dapat dikatan bahwa suplementasi MVM mempengaruhi asupan energi yang semula defisit berat menjadi defisit ringan, dan mempengaruhi asupan protein yang semula defisit tingkat ringan menjadi normal.

Tabel 4

Tingkat Kecukupan Sampel dari Makanan Sebelum dan Setelah Suplementasi

\begin{tabular}{ccccccc}
\hline & \multicolumn{6}{c}{ Perlakuan } \\
\cline { 2 - 7 } Zat Gizi & \multicolumn{2}{c}{ Plasebo } & \multicolumn{2}{c}{ Vit. C } & \multicolumn{2}{c}{ MVM } \\
\cline { 2 - 7 } & $\begin{array}{c}\text { Sebelum } \\
\text { (\% AKG) }\end{array}$ & $\begin{array}{c}\text { Setelah } \\
(\% \text { AKG) }\end{array}$ & $\begin{array}{c}\text { Sebelum } \\
(\% \text { AKG) }\end{array}$ & $\begin{array}{c}\text { Setelah } \\
(\% \text { AKG) }\end{array}$ & $\begin{array}{c}\text { Sebelum } \\
(\% \text { AKG) }\end{array}$ & $\begin{array}{c}\text { Setelah } \\
(\% \text { AKG) }\end{array}$ \\
\hline Energi & 69,6 & $68,9^{*}$ & 70,6 & $67,0^{*}$ & 58,5 & $78,4^{*}$ \\
Protein & 87,6 & $81,8^{*}$ & 87,0 & $84,4^{*}$ & 76,5 & $93,6^{*}$ \\
\hline
\end{tabular}

Keterangan: " berbeda nyata ( $p<0,05$; uji t berpasangan sebelum dan setelah suplementasi) 
Tabel 5

Rata-rata ( \pm SD) BB, IMT, TD Sistolik dan Diastolik, Kadar Urea dan Kreatinin Serum Darah Sebelum dan Setelah Suplementasi

\begin{tabular}{lcccccc}
\hline \multirow{2}{*}{ Variabel } & \multicolumn{7}{c}{ Perlakuan } \\
\cline { 2 - 7 } & \multicolumn{2}{c}{ Plasebo } & \multicolumn{2}{c}{ Vit. C } & \multicolumn{2}{c}{ MVM } \\
\cline { 2 - 6 } & Sebelum & Setelah & Sebelum & Setelah & Sebelum & Setelah \\
\hline BB $(\mathrm{kg})$ & $54,5 \pm 9,6$ & $54,5 \pm 9,6^{*}$ & $51,1 \pm 8,3$ & $50,6 \pm 7,9^{*}$ & $52,3 \pm 6,9$ & $52,0 \pm 6,7^{*}$ \\
IMT $\left(\mathrm{kg} / \mathrm{m}^{2}\right)$ & $23,7 \pm 3,6$ & $23,7 \pm 3,7^{*}$ & $22,5 \pm 3,4$ & $22,4 \pm 3,4^{*}$ & $23,2 \pm 2,3$ & $23,2 \pm 2,4^{*}$ \\
TD sistolik (mmHg) & $100 \pm 13,1$ & $99 \pm 11,4^{*}$ & $98 \pm 8,2$ & $95 \pm 6,8^{*}$ & $99 \pm 14,1$ & $97 \pm 9,5^{*}$ \\
TD diastolik (mmHg) & $66 \pm 7,6$ & $66 \pm 8,0^{*}$ & $65 \pm 5,1$ & $65 \pm 5,1^{*}$ & $66 \pm 8,4$ & $65 \pm 9,3^{*}$ \\
Urea (mg/dl) & $19,5 \pm 4,9$ & $21,2 \pm 5,0^{*}$ & $19,2 \pm 5,0$ & $20,8 \pm 4,6^{*}$ & $22,1 \pm 6,4$ & $21,4 \pm 4,2^{*}$ \\
Kreatinin (mg/dl) & $0,8 \pm 0,1$ & $0,8 \pm 0,1^{*}$ & $0,8 \pm 0,1$ & $0,8 \pm 0,1^{*}$ & $0,8 \pm 0,1$ & $0,9 \pm 0,1^{*}$ \\
\hline Keterangan: ${ }^{*}$ tidak berbeda nyata $(\mathrm{p}>0,05 ;$ uji t berpasangan sebelum dan setelah suplementasi)
\end{tabular}

Dari tabel di atas dapat dilihat bahwa pada variabel IMT, rata-rata sampel baik sebelum maupun setelah suplementasi berstatus gizi baik (IMT $18,5-24,9 \mathrm{~kg} / \mathrm{m}^{2}$ ). Pada tekanan darah sistolik dan diastolik, rata-rata sampel baik sebelum maupun setelah suplementasi termasuk dalam kategori tidak hipertensi (sistolik $<140 \mathrm{mmHg}$ dan diastolik $<90 \mathrm{mmHg}$ ). Pada kadar urea, rata-rata sampel sebelum maupun setelah suplementasi termasuk dalam kategori normal (urea 8,0-25,0 mg/dl). Demikian pula pada kadar kreatinin, baik sebelum maupun setelah suplementasi rata-rata sampel termasuk dalam kategori normal (kreatinin $0,6-1,5 \mathrm{mg} / \mathrm{dl})$.

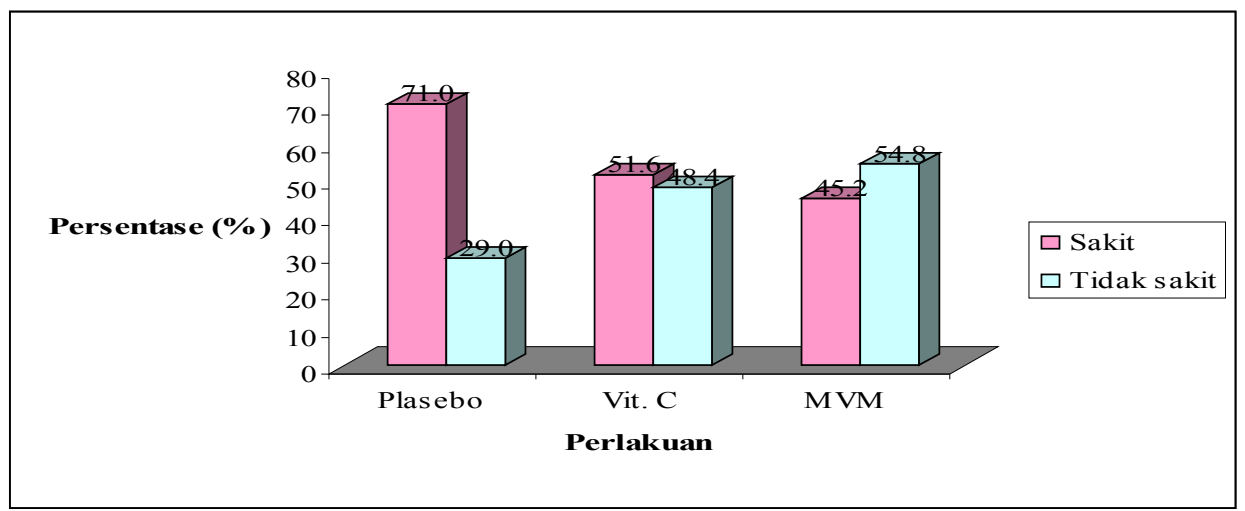

Gambar 1 Distribusi Wanita Pekerja Berdasarkan Kondisi Kesehatan

Jumlah sampel sakit selama suplementasi (10 minggu) diketahui melalui wawancara yang ditanyakan sekali dalam seminggu. Berdasarkan kondisi kesehatan, yakni sakit (ada keluhan penyakit infeksi) dan tidak sakit (tidak ada keluhan penyakit infeksi), didapatkan bahwa perlakuan dengan jumlah wanita pekerja yang terbanyak mengalami sakit adalah perlakuan plasebo, diikuti oleh perlakuan vitamin C, dan multivitamin mineral.

\section{BAHASAN}

Sampel penelitian ini adalah wanita pekerja karena wanita pekerja merupakan kelompok wanita usia subur yang rawan terkena masalah kurang gizi mikro. Masalah ini selain disebabkan oleh stress, baik stres 
lingkungan ${ }^{8}$ maupun stres karena beban kerja $^{9}$, disebabkan pula karena mereka cenderung melakukan diet dan mengalami menstruasi secara berkala.

Hasil penelitian menunjukkan bahwa suplementasi multivitamin mineral berpengaruh terhadap tingkat konsumsi energi dan protein sampel, dimana terjadi peningkatan asupan energi dan protein dari makanan oleh sampel. Hasil ini sejalan dengan penelitian ${ }^{10}$ yang menunjukkan bahwa wanita yang menggunakan suplemen mengkonsumsi lebih banyak energi dari wanita yang tidak menggunakan suplemen. Dalam $^{11}$ ditambahkan, konsumsi makanan pengguna suplemen lebih baik dibandingkan orang yang tidak menggunakan suplemen. Hal ini diduga karena semakin baiknya metabolisme dalam tubuh dengan adanya tambahan vitamin dan mineral dari suplemen.

Suplementasi multivitamin mineral dan vitamin C tidak mempengaruhi BB dan IMT sampel. Hal ini dapat dilihat pada rata-rata IMT sampel yang tidak mengalami perubahan, dimana rata-rata sampel termasuk dalam status gizi baik (IMT 18,5 $\left.24,9 \mathrm{~kg} / \mathrm{m}^{2}\right)$. Hasil ini sesuai dengan hasil penelitian ${ }^{12}$ serta $^{13}$ yang menunjukkan bahwa tidak terdapat perbedaan yang nyata terhadap BB perlakuan plasebo maupun perlakuan suplementasi sebelum dan setelah suplementasi, dan dalam ${ }^{14}$ dilaporkan berdasarkan data National Health and Nutrition Examination Survey tahun 19992000 di Amerika ditemukan bahwa pengguna suplemen multivitamin mineral lebih banyak berstatus gizi baik.

Hasil penelitian menunjukkan bahwa suplementasi multivitamin mineral maupun vitamin C tidak berpengaruh terhadap tekanan darah sistolik dan diastolik sampel. Baik sebelum maupun setelah suplementasi, sebagian besar wanita pekerja termasuk dalam kategori tidak hipertensi. Sebelum dan setelah suplementasi dilakukan, persentase wanita pekerja yang tidak mengalami hipertensi adalah 97,8 persen. Dalam penelitian ini, rendahnya tekanan darah (sistolik $<120 \mathrm{mmHg}$ dan diastolik <80 $\mathrm{mmHg}$ ) sampel diduga karena tingkat konsumsi sampel yang rendah. Selain itu, kondisi ini kemungkinan disebabkan pula oleh waktu istirahat yang kurang dan beban kerja sampel yang berat, dimana pada saatsaat tertentu wanita pekerja harus bekerja lembur 2 shift $(2 \times 8$ jam) sehari.

Pengaruh suplementasi multivitamin mineral dan vitamin $C$ selama 10 minggu terhadap kadar urea dan kreatinin serum darah menunjukkan bahwa fungsi ginjal wanita pekerja setelah suplementasi selama 10 minggu tidak terganggu. Hal ini dapat dilihat dari nilai rata-rata kadar urea yang masih berada dalam batas normal (8,0-25,0 $\mathrm{mg} / \mathrm{dl})$ dan kadar kreatinin yang juga masih berada dalam batas normal (0,6-1,5 mg/dl). Hal ini diduga disebabkan karena kandungan multivitamin mineral dan vitamin $C$ yang masih berada di bawah nilai batas tertinggi (tolerable upper intake level/UL) meskipun konsumsi protein pada perlakuan vitamin $\mathrm{C}$ cukup (tingkat konsumsi $80-90 \%$ ) bahkan lebih dari cukup pada perlakuan multivitamin mineral (tingkat konsumsi $>90 \%$ ). Dalam ${ }^{15}$ disebutkan bahwa salah satu faktor yang dapat mempengaruhi kadar urea dalam darah adalah konsumsi protein. Ditambahkan dalam ${ }^{16}$, bahwa suplemen vitamin C $\leq 2000 \mathrm{mg} /$ hari aman untuk sebagian besar orang dewasa. Beberapa zat gizi seperti vitamin $A$ dan mangan sangat berbahaya bila dikonsumsi dalam jumlah yang besar, sedangkan zat gizi lainnya seperti vitamin $\mathrm{C}$ dan besi memiliki efek berbahaya yang lebih kecil. Resiko bahaya mengkonsumsi suplemen makanan bergantung pada 3 faktor, yaitu batas aman zat gizi, kerentanan individu, dan kemungkinan asupan zat gizi yang sama dari suplemen lainnya atau dari makanan ${ }^{17}$.

Persentase wanita pekerja yang menderita sakit selama suplementasi pada perlakuan plasebo adalah 71,0 persen; pada perlakuan vitamin $C$ adalah 51,6 persen; sedangkan pada perlakuan multivitamin mineral adalah 45,2 persen. Menurut ${ }^{18}$, pengguna suplemen cenderung memiliki status kesehatan yang lebih baik dibandingkan orang yang tidak menggunakan suplemen. Dalam ${ }^{19}$ menyatakan, asupan beberapa jenis vitamin 
dan mineral seperti asam folat, vitamin $E$, selenium, kalsium, dan kromium yang melebihi recommended dietary allowance (RDA) dapat mengurangi resiko beberapa penyakit kronis seperti jantung dan kanker. Selanjutnya ${ }^{20}$ menambahkan, suplementasi vitamin $\mathrm{E}$ dan $\mathrm{C}$ dari sayur dan buah dapat meningkatkan sistem imun (proliferasi limfosit dan aktifitas sitotoksik sel natural killer). Selain itu ${ }^{21}$ juga menemukan bahwa zat gizi antioksidan (vitamin $\mathrm{C}, \mathrm{E}, \beta$ karoten, dan selenium) dihubungkan dengan lebih baiknya fungsi paru-paru.

\section{SIMPULAN}

1. Suplementasi multivitamin mineral memperbaiki tingkat kecukupan energi dan protein sampel.

2. Suplementasi vitamin C dan multivitamin mineral selama 10 minggu tidak berpengaruh terhadap status gizi sampel berdasarkan indeks massa tubuh (IMT).

3. Suplementasi vitamin C dan multivitamin mineral selama 10 minggu tidak berpengaruh terhadap status kesehatan sampel berdasarkan tekanan darah sistolik dan diastolik, serta kadar urea dan kreatinin serum darah.

4. Suplementasi vitamin C dan multivitamin mineral selama 10 minggu dapat mengurangi jumlah sampel sakit.

\section{SARAN}

Suplemen hendaknya dikonsumsi jika kebutuhan zat gizi dari makanan tidak mencukupi.

\section{RUJUKAN}

1. NIH State of the Science Panel. National Institute of Health State-of-the Science Conference Statement: Multivitamin/mineral supplements and chronic disease prevention. Am J Clin Nutr, 2007. 85:257S-264S.
2. Read NW. Placebo and Panacea: The Healing Effect of Nutritional Supplements. Di dalam: Ransley JK, Donnelly JK, Read NW, editor. Food and Nutritional Supplements Their Role in Health and Disease. Jerman: Springer, 2001.

3. Neuhouser ML. Dietary supplement use by American women: challenges in assessing patterns of use, motives and costs. J Nutr, 2003. 133:1992S-1996S.

4. Departemen Kesehatan Republik Indonesia. Komposisi Zat Gizi Pangan Indonesia. Jakarta: Depkes, 1990.

5. Departemen Kesehatan Republik Indonesia. Pedoman Praktis Menilai Status Gizi Orang Dewasa. Jakarta: Depkes, 1996.

6. $[\mathrm{AHA}]$ American Heart Association. 2000. About blood pressure. http://www.americanheart.org/highblood pressure [7 Juli 2008].

7. Kumar P, Clark M. Clinical Medicine. Ed ke-6. Edinburgh: Elsevier Saunders, 2005.

8. Romieu T. Nutrition and lung health. Int J Tuberc Lung Dis, 2005, 9:362-374.

9. Nieman DC. Does exercise alter immune function and respiratory infections? President's Council on Physical Fitness and Sports. Research Digest, 2001. 3(13).

10. Slesinski MJ, Subar AF, Kahle LL. Dietary intake of fat, fiber, and other nutrients is related to the use of vitamin and mineral supplements in the United States: The 1992 National Health Interview Survey. J Nutr, 1996. 126:3001-3008.

11. McNaughton SA, Mishra GD, Paul AA, Prynne CJ, Wadsworth MEJ. Supplement use is associated with health status and health-related behaviors in the 1946 British birth cohort. J Nutr, 2005. 135:1782-1789. 
12. Singh A, Moses FM, Deuster PA. Vitamin and mineral status in physically active men: effects of a high-potency supplement. Am J Clin Nutr, 1992. 55:17.

13. Bunout $D$, Barrera $G$, de la Maza $P$, Avendano M, Gattas V, Petermann M, Hirsch S. The impact of nutritional supplementation and resistance training on the health functioning of free-living Chilean elders: results of 18 months of follow-up. J Nutr, 2001. 131:2441S$2446 S$.

14. Radimer K, et al. Dietary supplement use by US adults: data from the National Health and Nutrition Examination Survey, 1999-2000. Am J Epidemiol, 2004. 160:339-349.

15. Kotchen TA, Kotchen JM. Nutrition, Diet, and Hypertension. Di dalam: Shils ME, Shike M, Ross C, Caballero B, Cousins RJ, editor. Modern Nutrition in Health and Disease. Ed ke-10. Baltimore: Lippincot Williams \& Wilkins, 2006.

16. Hathcock JN, et al. Vitamins $E$ and $C$ are safe across a broad range of intakes. Am J Clin Nutr, 2005. 81:736745.

17. Mulholland CA, Benford DJ. What is known about the safety of multivitaminmultimineral supplements for the generally healthy population? Theoretical basis for harm. Am J Clin Nutr, 2007. 85:318S-322S.

18. McNaughton SA, Mishra GD, Paul AA, Prynne CJ, Wadsworth MEJ. Supplement use is associated with health status and health-related behaviors in the 1946 British birth cohort. J Nutr, 2005. 135:1782-1789.

19. Hathcock JN. Vitamins and minerals: efficacy and safety. Am J Clin Nutr, 1997. 66:427-437.

20. Zakaria FR, Irawan B, Pramudya SM, Sanjaya. Intervensi sayur dan buah pembawa vitamin $\mathrm{C}$ dan vitamin $\mathrm{E}$ meningkatkan sistem imun populasi buruh pabrik di Bogor. Bul Teknol dan Industri Pangan, 2000. XI(2):21-27.

21. Hu G, Cassano PA. Antioxidants nutrients and pulmonary function: the third national health and nutrition examination survey (NHANES III). Am J Epidemiol, 2000. 151(10):975-981. 